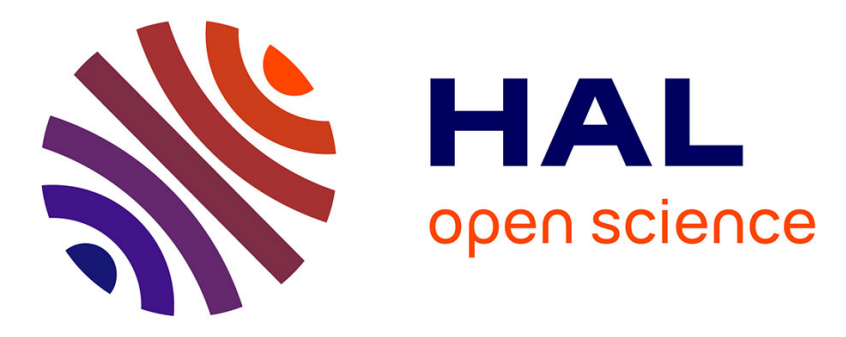

\title{
Pro-apoptotic meiogynin A derivatives that target Bcl-xL and Mcl-1.
}

Sandy Desrat, Anaïs Pujals, Claire Colas, Jérémy Dardenne, Loëtitia Favre, Vincent Dumontet, Bogdan I Iorga, Marc Litaudon, Martine Raphaël, Fanny Roussi

\section{To cite this version:}

Sandy Desrat, Anaïs Pujals, Claire Colas, Jérémy Dardenne, Loëtitia Favre, et al.. Pro-apoptotic meiogynin A derivatives that target Bcl-xL and Mcl-1.. Bioorganic and Medicinal Chemistry Letters, 2014, 24 (21), pp.5086-5088. 10.1016/j.bmcl.2014.09.004 . hal-01077156

\section{HAL Id: hal-01077156 https://hal.science/hal-01077156}

Submitted on 7 Mar 2021

HAL is a multi-disciplinary open access archive for the deposit and dissemination of scientific research documents, whether they are published or not. The documents may come from teaching and research institutions in France or abroad, or from public or private research centers.
L'archive ouverte pluridisciplinaire HAL, est destinée au dépôt et à la diffusion de documents scientifiques de niveau recherche, publiés ou non, émanant des établissements d'enseignement et de recherche français ou étrangers, des laboratoires publics ou privés. 


\title{
Pro-apoptotic meiogynin A derivatives that target Bcl-xL and Mcl-1
}

\author{
Sandy Desrat ${ }^{\mathrm{a}}$, Anaïs Pujals ${ }^{\mathrm{b}}$, Claire Colas ${ }^{\mathrm{a}}$, Jérémy Dardenne ${ }^{\mathrm{a}}$, Charlotte Gény ${ }^{\mathrm{a}}$, Loëtitia Favre ${ }^{\mathrm{b}}$, Vincent \\ Dumontet $^{\mathrm{a}}$, Bogdan I. Iorga ${ }^{\mathrm{a}}$, Marc Litaudon ${ }^{\mathrm{a}}$, Martine Raphaël ${ }^{\mathrm{b}}$, Joëlle Wiels ${ }^{\mathrm{b}}$, and Fanny Roussi ${ }^{\mathrm{a}}$
}

${ }^{a}$ Institut de Chimie des Substances Naturelles, CNRS UPR 2301, 1 avenue de la terrasse, 91198 Gif-sur-Yvette Cedex, France

${ }^{b}$ UMR CNRS 8126, Univ Paris-Sud, Institut Gustave Roussy, 114 rue Edouard-Vaillant, 94805 Villejuif Cedex, France

\section{ARTICLE INFO}

Article history:

Received

Revised

Accepted

Available online

\section{Keywords:}

Sesquiterpene Dimer

Apoptosis

Bcl-xL

Mcl-1

Molecular docking

\section{ABSTRACT}

The biological evaluation of a natural sesquiterpene dimer meiogynin A $\mathbf{1}$, is described as well as that of five non-natural analogues. Although active on a micromolar range on the inhibition of Bcl-xL/Bak and Mcl-1/Bid interaction, meiogynin A $\mathbf{1}$ is not cytotoxic on three cell lines that overexpress Bcl-xL and Mcl-1. Contrarily, one of its analogues $\mathbf{6}$ with an inverted configuration on the side chain and an aromatic moiety replacing the cyclohexane ring was active on both target proteins, cytotoxic on a micromolar range and was found to induce apoptosis through a classical pathway.
Multicellular organisms use apoptosis to regulate tissue homeostasis through the elimination of useless or potentially harmful cells. Key players of apoptosis are caspases, a family of proteases whose activation is induced by two major signalling pathways among which the intrinsic pathway that is regulated by proteins of the Bcl-2 family. This family is divided into antiapoptotic members such as Bcl-2, Bcl-xL or Mcl-1 and proapoptotic members such as Bax, Bak or Bid. The anti-apoptotic proteins bind and thus neutralize the pro-apoptotic ones via a hydrophobic cleft through protein-protein interactions. Over the past decade, it was shown that overexpression of the antiapoptotic Bcl-2, Bcl-xL or Mcl-1 proteins is involved in the development of many kinds of cancers or confers resistance to apoptosis induced by standard anticancer therapies. ${ }^{1,2}$ For example, proteins of the Bcl-2 family play a central role in lymphocytes biology and are very often deregulated in lymphoid malignancies. ${ }^{3}$ Consequently, targeting this family of proteins is a highly promising strategy for tumor treatment. The feasibility of disrupting protein-protein interactions between anti- and proapoptotic members of the Bcl-2 family, using small-molecule inhibitors has been successfully established. ${ }^{4}$ Three smallmolecule inhibitors have entered human clinical trials ${ }^{5}$ and at least three other compounds are in preclinical studies. Antiapoptotic protein inhibitors can be classified in two distinct groups:

- Pan-inhibitors targeting various proteins of this family (Bcl$\mathrm{xL}, \mathrm{Bcl}-2$ and Mcl-1), including $R$-(-)-gossypol (AT-101) and obatoclax ${ }^{6}$ that are currently in clinical trials. They are active at a micro-molar concentration on the target proteins and are more efficient in combination with other drugs.
- Selective inhibitors of a subset of proteins, targeting either Bcl-xL like navitoclax ${ }^{7}$ and WEHI-539 ${ }^{8}$, or Bcl-2 like ABT $199^{8}$ or Mcl-1. In the latter case, the only reported compounds ${ }^{10}$ are not druggable but are rather regarded as potent leads. All these compounds are highly active with a $\mathrm{Ki}$ at a nano-molar level. Nevertheless, for those used in clinical trials, resistance due to overexpression of the non-targeted proteins (mainly Mcl-1) was identified suggesting that efficient treatment may require simultaneous inhibition of multiple anti-apoptotic Bcl-2 proteins. $^{11}$

Natural products or derivatives of natural products represent $75 \%$ of the 175 drugs used in cancer chemotherapy. ${ }^{12}$ In 2008 , we conducted a biological screening on Malaysian plant extracts, leading to the isolation of a new sesquiterpene dimer that we named meiogynin A 1. ${ }^{13}$ This compound was found to be a natural antagonist of the $\mathrm{Bcl}-\mathrm{xL} / \mathrm{Bak}$ association. Its biomimetic asymmetric total synthesis was then disclosed ${ }^{14}$ and enabled the elaboration of three additional unnatural analogues 2-4. Later on, two aromatic compounds $\mathbf{5}$ and $\mathbf{6}$ were also prepared (Figure 1). ${ }^{15}$ In this paper, the biological evaluation of meiogynin A $\mathbf{1}$, as well as that of its non-natural analogs 2-6, is disclosed. 

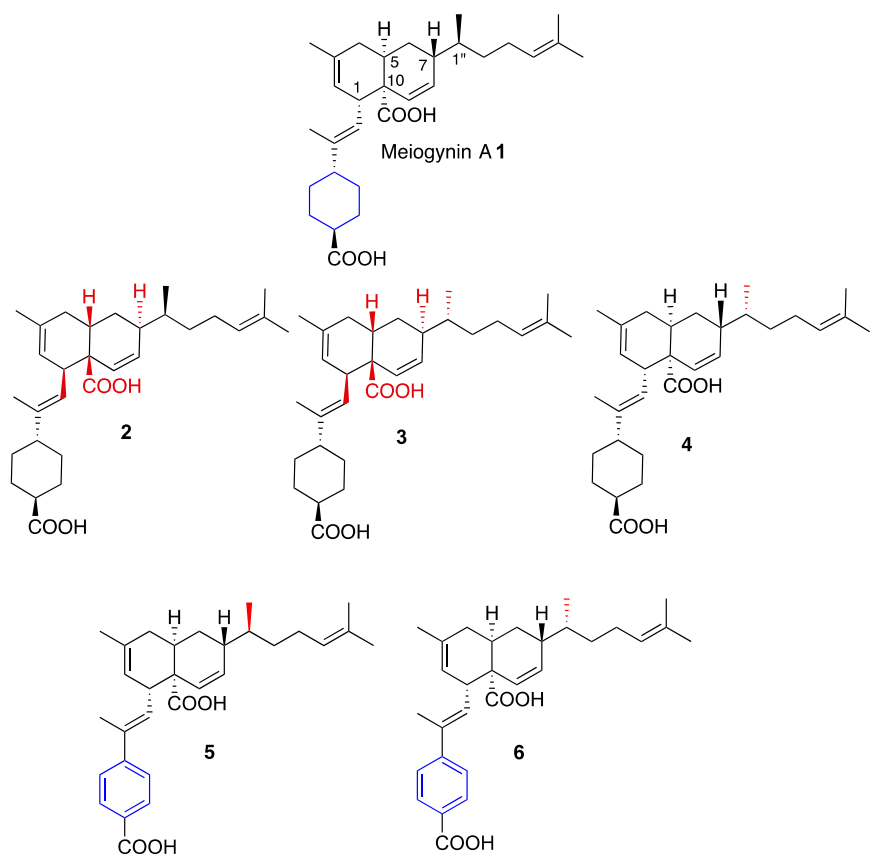

Figure 1. Structure of natural meiogynin A 1 and synthetic analogues 2-6.

The binding affinities of natural and unnatural sesquiterpene dimer type-compounds 1-6 for Bcl-xL and Mcl-1 were evaluated by competition against fluorescently labeled peptides Bak and Bid respectively, using an assay adapted from Qian and coworkers. $^{16}$

The results of the biological assays are summarized in Table 1 .

The binding affinities for Bcl-xL are closely related to the absolute configuration of the five stereocenters. Thus, the enantiomer $\mathbf{3}$ of meiogynin A $\mathbf{1}$ is inactive, whereas the diastereomer $\mathbf{4}$ that only differs from $\mathbf{1}$ by the configuration at $\mathrm{C} 1$ " is three times more potent. Its enantiomer $\mathbf{2}$ is moderately active. The aromatic analogues behave the same way: compound 6 (analogue of 4) is slightly more active than 5 (analogue of natural 1). In contrast, binding affinities for Mcl-1 are all on the same level regardless of their absolute configuration. The potency of the aromatic analogues $\mathbf{5}$ and $\mathbf{6}$ are a little weaker than 1 and 4. Nevertheless, taken together, these results emphasize the fact that changing the cyclohexane moiety by an aromatic group has no real influence on the inhibition of Bcl-xL/Bak and Mcl1/Bid interaction.

Table 1. Inhibition of Bcl-xL/Bak and Mcl-1/Bid interaction

\begin{tabular}{ccc}
\hline Compound & $K$ i Bcl-xL/Bak $(\mu \mathrm{M})^{\mathrm{a}, \mathrm{b}}$ & $K$ i Mcl-1/Bid $(\mu \mathrm{M})^{\mathrm{a}, \mathrm{b}}$ \\
\hline $\mathbf{1}$ & $9.0 \pm 0.4$ & $3.8 \pm 0.2$ \\
$\mathbf{2}$ & $100 \pm 13$ & $14.4 \pm 0.9$ \\
$\mathbf{3}$ & $40 \pm 9$ & $12.9 \pm 0.4$ \\
$\mathbf{4}$ & $2.3 \pm 0.7$ & $4.2 \pm 0.9$ \\
$\mathbf{5}$ & $7.5 \pm 0.5$ & $15.9 \pm 0.6$ \\
$\mathbf{6}$ & $4.6 \pm 1.5$ & $9.1 \pm 0.5$
\end{tabular}

${ }^{\mathrm{a}} \mathrm{Ki}$ is the concentration corresponding to $50 \%$ of inhibition of the binding of the labeled reference compound Bak to Bcl-xL and Bid to Mcl-1, and corrected for experimental conditions according to Cheng and Prussof. ${ }^{17}$ b Values are reported as the means of three independent determinations.

The cytotoxicities of all the compounds were evaluated on Burkitt lymphoma (BL) cell lines (BL2, BL2/B95) and lymphoblastoid (Remb1) cell lines (LCL), that were previously shown to express both Bcl-xL and Mcl-1. ${ }^{18}$ Cells were treated, or not, with various concentrations of compounds 1-6 and cytotoxicities were evaluated by MTT assays. As shown in
Figure 2, compound 6, contrarily to meiogynin A 1, was cytotoxic for the three cell lines since more than $50 \%$ of the cells were killed after $24 \mathrm{~h}$ of treatment with $10 \mu \mathrm{M}$ of this compound. $\mathrm{IC}_{50}$ of compound 6 were determined to be of $8.5 \mu \mathrm{M}$ for BL2 and $8.6 \mu \mathrm{M}$ for BL2/B95 and Remb1. In contrast, the other compounds $2-5$ were not cytotoxic for the cells $\left(\mathrm{IC}_{50}>20 \mu \mathrm{M}\right.$, data not shown).

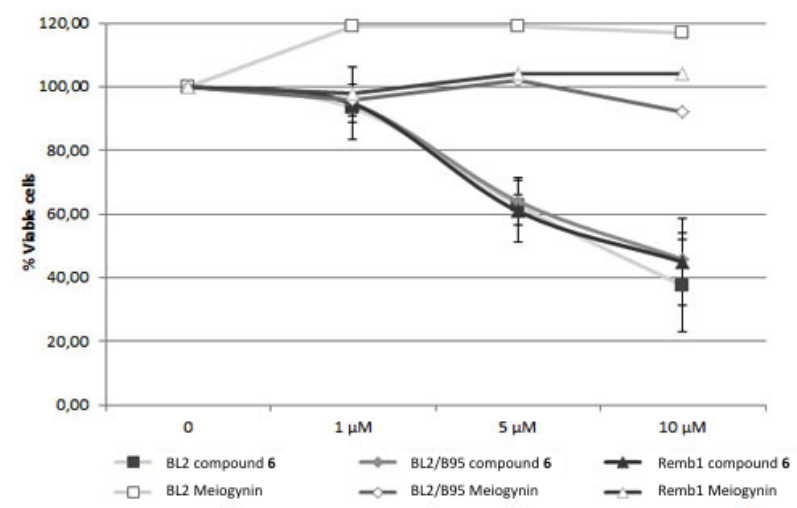

Figure 2. Cytotoxicity evaluation of compound 6 in BL and LCL. Cells were treated, or not, with various concentration of compound $\mathbf{6}$ for $24 \mathrm{~h}$. After cell lysis, an MTT assay was performed and cell viability was determined by reading the absorbance at $550 \mathrm{~nm}$. Results are expressed in percentage as compared to untreated cells. The values presented (mean \pm s.d.) are from three independent experiments.

We then confirmed that the cytotoxic effect of compound 6 was due to its ability to induce apoptosis. Apoptosis was first assessed by flow cytometry, after labeling the cells with annexin-V-FITC and PI. As shown in Figure 3, treatment with $7.5 \mu \mathrm{M}$ of compound 6 for $24 \mathrm{~h}$ strongly induced apoptosis in all cell lines ( $71 \pm 3.8 \%, 52 \pm 14 \%$ and $54 \pm 14 \%$ of apoptotic cells for BL2, BL2/B95 and Remb1 respectively).

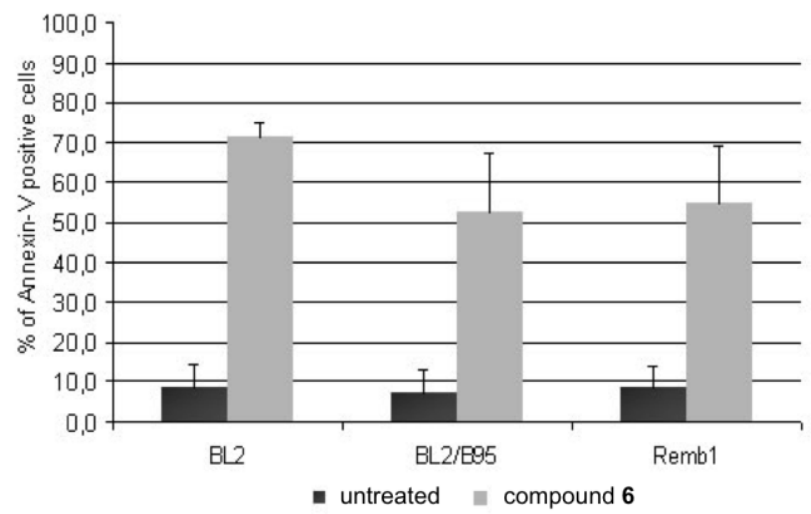

Figure 3. Effects of compound 6 treatment on the induction of apoptosis in BL and LCL. Cells were treated or not with $7.5 \mu \mathrm{M}$ of compound 6 for $24 \mathrm{~h}$. Cells were labeled with annexin-V-FITC and PI and analyzed with a FACSCalibur flow cytometer to determine the percentage of apoptotic cells. The values presented (mean \pm s.d.) are from three independent experiments.

Next, apoptosis was confirmed by measuring the cleavage of polyadenosine diphosphate ribose polymerase (PARP), a direct target of caspase-3, by western blots. Thus, treatment with compound 6 induced a strong cleavage of PARP (Figure 4). 


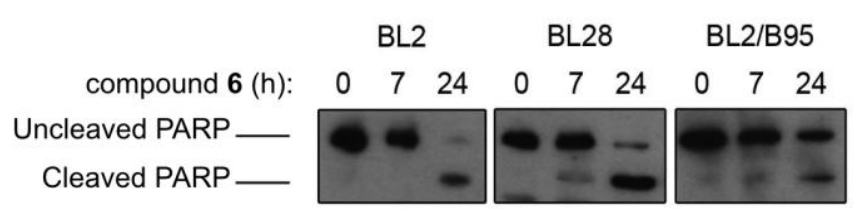

Figure 4. Effects of compound 6 treatment on PARP cleavage. Cells were treated, or not, with $7.5 \mu \mathrm{M}$ of compound 6 for $24 \mathrm{~h}$. Apoptosis levels were determined by assessing polyadenosine diphosphate-ribose polymerase (PARP) cleavage on western blots. The data are representative of at least three independent experiments.

Finally, in order to identify the nature of the interactions between compound $\mathbf{6}$ and Bcl-xL, at the molecular level, docking calculations were carried out using a conformer of Bcl-xL generated previously using a ligand-driven conformer selection from molecular dynamics simulations ${ }^{19,20}$ that was found to be the most relevant for the interaction with compounds of the meiogynin A family. ${ }^{19,20}$ Compound $\mathbf{6}$ is accommodated in the binding site in a similar way to meiogynin A 1, with interactions that are predominantly hydrophobic (Figure 5). The only notable exception is the ionic interaction between the carboxylate substituent of the bicyclic system and the side chain of Arg139, which most likely provides a major contribution to the overall binding affinity.

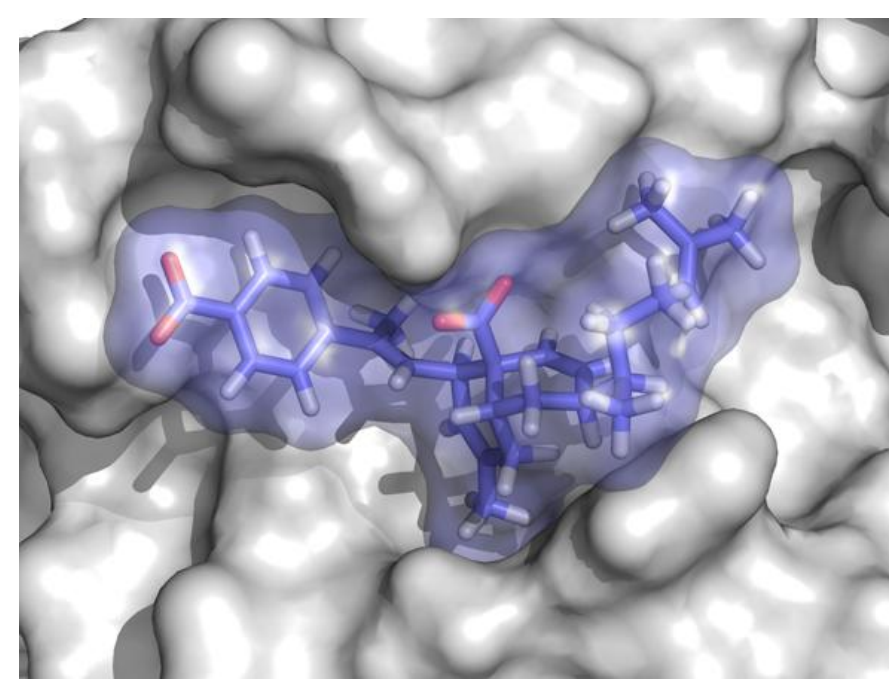

Figure 5. Docking complex of compound 6, colored in blue, with a selected conformation of Bcl-xL.

In conclusion, the potential of synthetic analogues of a natural sesquiterpene dimer as dual Mcl-1 and Bcl-xL inhibitors was disclosed. Indeed, compound $\mathbf{6}$ was found to be active on these two proteins, cyototoxic at the micromolar range on three lymphoid cell lines and was shown to induce apoptotic cell death through a classical pathway involving caspase proteases. These compounds form a new family of dual Bcl-xL and Mcl-1 inhibitors. Work is currently underway in our laboratory ${ }^{20}$ in order to elaborate new analogs of meiogynin A 1 with improved cytotoxicity and anti-apoptotic properties.

\section{Acknowledgments}

This work is supported in part by the contract ANR-2010-JCJC-702-1 ApoMeioA (FR) and by grants from the Fondation de France 00012093 (JW), the Cancéropole and Région Ile-de-France (ERABL, IF09-2092/R).

\section{References and notes}

1. Lessene, G.; Czabotar, P. E.; Colmna, P. M. Nat. Rev. Drug Discovery, 2008, 989.

2. Warr, M.R.; Shore, J. C. Curr. Mol. Med. 2008, 8, 138.

3. Reed, J.C. Blood 2008, 111, 3322.

4. Davids, M. S.; Letay, A. J. Clin. Oncol. 2012, 30, 3127.

5. Bajwa, N.; Lia, C.; Nikolovska-Coleska, Z. Expert Opin. Ther. Pat. 2012, 22, 37.

6. Goard, C. A.; Shimmer, A. D. Core Evid. 2013, 8, 15

7. Gandhi, L.; Ross Camidge, D.; Ribeiro de Oliveira, M.; Bonomi, P.; Gandara, D.; Khaira, D.; Hann, C. L.; McKeegan, E. M.; Litvinovich, E.; Hemken, P. M.; Dive, C.; Enschede, S. H.; Nolan, C.; Chiu, Y.-L.; Busman, T.; Xiong, H.; Krivoshik, A. P.; Humerickhouse, R.; Shapiro, G. I.; Rudin, C. M. J. Clin. Oncol. 2011, 29, 909.

8. Lessene, G.; Czabotar, P. E.; Sleebs, B. E.; Zobel, K.; Lowes, K. N.; Adams, J. M.; Baell, J. B.; Colman, P. M.; Deshayes, K.; Fairbrother, W. J.; Flygare, J. A.; Gibbons, P.; Kersten, W. J. A.; Kulasegaram, S.; Moss, R. M.; Parisot, J. P.; Smith, B. J.; Street, I. P.; Yang, H.; Huang, D. S. C.; Keith G Watson, K. G. Nature Chemical Biology 2013, 9, 390.

9. Souers, A. J.; Leverson, J. D.; Boghaert, E. R.; Ackler, S. L.; Catron, N. D.; Chen, J.; Dayton, B. D.; Ding, H.; Enschede, S. H.; Fairbrother, W. J.; Huang, D. S. C.; Hymowitz, S. G.; Jin, S.; Khaw, S. L.; Kovar, P. J.; Lam, L. T.; Lee, J.; Maecker, H. L.; Marsh, K. C.; Mason, K. D.; Mitten, M. J.; Nimmer, P. M.; Oleksijew, A.; Park, C. H.; Park, C.-M. et al. Nature Medecine 2013, 19, 202.

10. Friberg, A.; Vigil, D.; Zhao, B.; Nathan Daniels, R.; Burke, J. P.; Garcia-Barrantes, P. M.; DeMarco Camper, D. M.; Chauder, B. A.; Lee, T.; Olejniczak, E. T.; Fesik, S. W. J. Med. Chem. 2013, 56,15 .

11. Jeng, P. S.; Cheng, E. H. Nature Chemical Biology. 2013, 9, 351.

12. Newman, D. J.; Cragg,G. M. J. Nat. Prod. 2012, 75, 311.

13. Litaudon, M.; Bousserouel, H.; Awang, K.; Nosjean, O.; Martin, M.-T.; Tran Huu Dau, M. E.; Hadi, H. A.; Boutin, J. A.; Sévenet, T.; Guéritte, F. J. Nat. Prod. 2009, 72, 480.

14. Fomekong-Fotsop, D.; Roussi, F.; Leverrier, A.; Bretéché, A.; Guéritte, F. J. Org. Chem. 2010, 75, 7412.

15. Dardenne, J.; Desrat, S.; Guéritte, F.; Roussi, F. Eur. J. Org. Chem. 2013, 2116.

16. Qian, J.; Voorbach, M. J.; Huth, J. R.; Coen, M. L.; Zhang, H.; Ng, S. C.; Comess, K. M.; Petros, A. M.; Rosenberg, S. H.; Warrior, U.; Burns, D. J. Anal Biochem 2004, 328, 131.

17. Cheng, Y.; Prusoff, W. H. Biochem Pharmacol 1973, 22, 3099.

18. Pujals, A.; Renouf, B.; Robert, A.; Chelouah, S.; Hollville, E.; Wiels, J. Cell Death \& Dis. 2011, 2, e184; doi:10.1038/cddis.2011.67.

19. Colas, C.; Roussi, F.; Iorga, B. I. "Focused ligand libraries as tools for in silico design of anti-apoptotic proteins inhibitors" in Chemistry for Life Sciences, eds. T. Kiss and A. Perczel, Medimond, Bologna, 2011, 41.

20. Desrat, S.; Remeur, C.; Gény, C.; Rivière, G.; Colas, C.; Dumontet, V.; Birlirakis, N.; Iorga, B. I.; Roussi, F. Chem. Commun., 2014,50, 8593. 